\title{
16: 13921524-13949705
}

National Cancer Institute

\section{Source}

National Cancer Institute. 16:13921524-13949705. NCI Thesaurus. Code C42210.

Physical location of ERCC4_Gene 